\title{
The Characterisation of Armed Conflict and Targeted Killing of Suspected Terrorists under International Humanitarian Law: Reflections on the Future of Jus in Bello
}

\author{
Dr. Sana Mir* and Dr. Anthony Cullen**
}

\section{Abstract}

The use of drones for the targeted killing of suspected terrorists has raised a number of complex legal issues for scholars and practitioners in field of international law. This paper will focus on the applicability of international humanitarian law in such situations and the characterisation of drone warfare as armed conflict.

In this context, the scope of armed conflict as a concept of international humanitarian law will be explored. In doing so, emphasis will be placed on the need for accountability to ensure greater compliance with international law.

Keywords: International law, drones, Unmanned Ariel Vehicles, international human rights law, war crimes, Vienna Convention on the Law of Treaty.

\footnotetext{
* Lecturer in Law School of Law, Middlesex University, London,UK.

** Senior Lecturer, School of Law, Middlesex University, London,UK. He currently teaches Public Law, International Criminal Law, and International Humanitarian law.
} 


\section{Introduction}

The targeted killing of suspected terrorists has in recent years been a subject of considerable controversy, in particular since the killing of Qaed Salim Sinan al-Harethi in 2002 by a Hellfire missile shot by a Predator drone. ${ }^{(1)}$ Concerns about the legality of such strikes have been raised by various UN Special Rapporteurs, including Philip Alston, the former Special Rapporteur Extrajudicial, Summary and Arbitrary Executions. ${ }^{(2)}$ In his 2010 report he stated that targeted killing by drones had led to a 'highly problematic blurring.... of the boundaries of the applicable legal frameworks'.(3) Alston commented that the result 'has been the displacement of clear legal standards with a vaguely defined license to kill' (4) The issue this paper seeks to address concerns the legal framework for the use of lethal force by armed drones, focusing in particular on the applicability of international humanitarian law. ${ }^{(5)}$

(1) Qaed Salim Sinan al-Harethi was killed by the CIA in Yemen using an unmanned Predator drone on 3 November 2002. See Chris Downes, “Targeted Killings” in an Age of Terror: The Legality of the Yemen Strike' (2004) 9 Journal of Conflict and Security Law 277-94; A P V Rogers, Law on the Battlefield (Oxford University Press 2013) 50-1; Noam Lubell, 'The War (?) against Al-Qaeda' in Elizabeth Wilmshurst (ed), International Law and the Classification of Conflicts (Oxford University Press 2012) P.450.

(2) Philip Alston, 'Special Rapporteur on Extrajudicial, Summary or Arbitrary Executions, "Study on Ta geted Killings,", (28 May 2010) UN Doc A/HRC/14/24/Add.6

(3) ibid

(4) ibid

(5) The use of armed drones engages a range of different legal issues, including rules of jus ad bellum. This paper will focus on the implications for jus in bello. For reading of a more general nature on the use of armed drones, see: Claire Finkelstein, Jens David Ohlin, and Andrew Altman, Targeted Killings: Law and Morality in an Asymmetrical World (Oxford University Press, 2012); Bradley Jay Strawser (ed), Killing by Remote Control: The Ethics of an Unmanned Military (Oxford University Press 2013); Dan Saxon, International Humanitarian Law and the Changing Technology of War (Brill, 2013); Marjorie Cohn and Desmond Tutu, Drones and Targeted Killing: Legal, Moral, and Geopolitical Issues (Interlink Publishing 2014); Sikander Ahmed Shah, International Law and Drone Strikes in Pakistan: The Legal and Socio-political Aspects (Routledge, 2014); James DeShaw Rae, Analyzing the Drone Debates: Targeted Killings, Remote Warfare, and Military Technology (Palgrave Macmillan, 2014); Sarah Knuckey (ed), Drones and Targeted Killings: Ethics, Law, Politics (International Debate Education Association 2014); John Kaag and Sarah Kreps, Drone Warfare (Wiley 2014); Steven Barela (ed), Legitimacy and Drones: Investigating the Legality, Morality and Efficacy of UCAVs (Ashgate, 2015); Aleš Završnik, Drones and Unmanned Aerial Systems: Legal and Social Implications for Security and Surveillance (Springer International Publishing, 2015); Peter Bergen and Daniel Rothenberg, Drone Wars (Cambridge University Press 2015); Jammel Jaffer (ed), The Drone Memos: Targeted Killing, Secrecy, and the Law (New Press, 2016); Ezio Di Nucci and Filippo Santoni de Sio, Drones and Responsibility: Legal, Philosophical and Socio-Technical Perspectives on Remotely Controlled Weapons (Taylor \& Francis 2016); Bart Custers (ed), The Future of Drone Use: Opportunities and Threats from Ethical and Legal Perspectives (Information Technology and Law Series, Springer, 2016); Hugh Gusterson, Drone: Remote Con- = 
It will begin first by providing context for the use of drones and examining the significance of characterising a situation as one of armed conflict for the targeted killing of suspect terrorists. It will then examine the applicability of international humanitarian law to armed drones and the legal basis for the use of lethal force beyond the boundaries of the conventional battlefield. In light of the object and purpose of international humanitarian law, it will be argued that States deploying drones are obligated to comply with international law. Accordingly, it is only by adherence to the letter and spirit of the law that the military interests of a State engaged in armed conflict can be preserved.

\section{The Proliferation of Drone Technology and the Context for the Use of Drones in Armed Conflict}

The technology enabling the use of drones can be traced back to the First World War. ${ }^{(6)}$ Until 2001 drones were for the most part used only for reconnaissance. ${ }^{(7)}$ They were employed for this purpose during the Vietnam War and in Kosovo. ${ }^{(8)}$ Compared to other weapons, the advantages of using drones are many but a chief factor is that they avoid risks to State forces. ${ }^{(9)}$ Drones became an everyday reality with the initiation of the 'war on terror' and are now a weapon of choice for militaries across the globe. ${ }^{(10)}$ Today, the proliferation of drones appears inevitable and, within a decade, it is predicted that almost every single country will have its own armed drones. ${ }^{(11)}$ At the time of writing, nine

$=$ trol Warfare (MIT Press 2016); Stuart Maslen, Nathalie Weizmann, Maziar Homayounnejad and Hilary Stauffer, Drones and Other Unmanned Weapons Systems under International Law (Brill 2018).

(6) Ian G.R. Shaw, 'The Rise of the Predator Empire: Tracing the History of U.S. Drones' $<$ https://unde standingempire.wordpress.com/2-0-a-brief-history-of-u-s-drones/ > accessed at 13 April 2019.

(7) Mark Mazzetti, The way of knife, the CIA, a secret army and a war at the ends of the earth (Scribe 2013) 91

(8) Josep Guerrero and Rogelio Lozano, Flight Formation Control, Chapter 1 1.22 Evolution of UAV's, (ISTE Ltd, 2012) ; JD R. Dixon, 'UAV Employment in Kosovo: Lessons for the Operational Commander' (Naval war college 2000).

(9) Peter W Singer, Wired for war: The robotics revolution and conflict in the 21st century (Penguin 2009) Pp.116-120

(10) For a discussion of how drones are defined, see: Roger Clarke, 'Understanding the drone epidemic' (2014) 30 (3) Computer Law \& Security Review Pp.230-246.

(11) Defence one, 'Every Country Will Have Armed Drones Within 10 Years' (6 May 2014) < http://www. defenseone.com/technology/2014/05/every-country-will-have-armed-drones-within-ten-years/83878/ > accessed 10 April 2019; The armed drones club has grown exponentially See Clay Dillow, 'All of These Countries Now Have Armed Drones' (Fortune, 12 Feb 2016) < http://fortune.com/2016/02/12/these-countrieshave-armed-drones/ > accessed at 19 July 2016; seven countries have used armed drones in combat: the United States, Israel, the United Kingdom, Pakistan, Iraq, Nigeria, and Iran See New America, 'World of Drones: Military'< http://securitydata.newamerica.net/world-drones.html > accessed 10 April 2019. 
countries including the UK, USA, Pakistan, Turkey, Israel, Iraq, Iran, Nigeria and Azerbaijan are using armed drones in combat. ${ }^{(12)}$ The rapid proliferation of drone technology among states and militant groups alike poses a new threat to the international community. Several non-state actors including ISIS, Hamas, Hezbollah, or Houthi rebels, have incorporated drones into their operations. ${ }^{(13)}$ Employed by both State and non-state actors, drones pose a diverse range of complex challenges to the regulatory framework for the use of armed force. The section that follows focuses on one of these challenges: the characterisation of armed conflict for the application of international humanitarian law to operations involving the use of lethal force.

\section{The Characterisation of Armed Conflict}

To determine the lawfulness or otherwise of lethal force by an armed drone, clarity is required on the applicable legal framework. The applicable legal framework is determined by the status of a situation: If the context is one of armed conflict, international humanitarian law will apply with significant implications for the use of lethal force. The significance of characterizing a situation as one of armed conflict was commented on by Philip Alston, the former UN Special Rapporteur on extrajudicial, summary or arbitrary executions, in his Study on Targeted Killings:

Outside the context of armed conflict, the use of drones for targeted killing is almost never likely to be legal. A targeted drone killing in a State's own territory, over which the State has control, would be very unlikely to meet human rights law limitations on the use of lethal force. ${ }^{(14)}$

As the existence of armed conflict has bearing on the legal framework for use of lethal force, it is essential to understand how situations are characterised as such under international humanitarian law. The most authoritative point of reference for the characterisation of armed conflict is provided in the case of Prosecutor $v$ Tadic before the International Criminal Tribunal for the former

(12) New America, "Who has What: Countries with drones used in combat", < https://www.newamerica.org/ in-depth/world-of-drones/2-who-has-what-countries-drones-used-combat/ > accessed 13 April 2019.

(13) New America, 'Non-State Actors with Drone Capabilities' < https://www.newamerica.org/in-depth/ world-of-drones/5-non-state-actors-drone-capabilities/ > accessed 14 April 2019.

(14) UN Special Rapporteur on Extrajudicial, Summary or Arbitrary Executions, Study on Targeted Kil ings, UN Doc A/HRC/14/24/Add.6, 28 May 2010, para 85. 
Yugoslavia. ${ }^{(15)}$ In its Decision on the Defence Motion for Interlocutory Appeal on Jurisdiction (the Tadic Jurisdiction Decision), the Appeals Chamber of the Tribunal defined the concept of armed conflict as follows:

[A]n armed conflict exists whenever there is a resort to armed force between States or protracted armed violence between governmental authorities and organized armed groups or between such groups within a State. International humanitarian law applies from the initiation of such armed conflicts and extends beyond the cessation of hostilities until a general conclusion of peace is reached; or, in the case of internal conflicts, a peaceful settlement is achieved. ${ }^{(16)}$

The definition propounded in Tadic Jurisdiction Decision was developed by the Tribunal as one of the tests required to determine the applicability of international humanitarian law for subject-matter jurisdiction over war crimes. In order for a situation to be characterised as one of armed conflict, there

(15) For discussion of the definition provided by the Tadic Appeals Chamber see: Anthony Cullen, The Concept of Non-International Armed Conflict in International Humanitarian Law (Cambridge University Press 2010) Pp.115-58.

(16) Prosecutor v Tadić, Decision on the Defence Motion for Interlocutory Appeal on Jurisdiction, 2 O tober 1995, ICTY Case No. IT-94-1-AR72, para. 70. This definition has been consistently applied in subsequent jurisprudence. See, e.g. Prosecutor v. Tadic, Trial Chamber Judgment, 7 May 1997, ICTY Case No. IT-94-1-AR72, para. 561; Prosecutor v. Delalic, Mucic, Delic and Landzo, Trial Chamber Judgment, 16 November 1998, ICTY Case No. IT-96-21-T, para. 183; Prosecutor v. Furundzija, Trial Chamber Judgment, 10 December 1998, ICTY Case No. IT-95-17/1, para. 59; Prosecutor v. Kordic and Cerkez, Trial Chamber Judgment, 26 February 2001, ICTY Case No. IT-95-14/2-T, para. 24; Prosecutor v. Kordic and Cerkez, Appeals Chamber Judgment, 26 February 17 December 2004, ICTY Case No. IT-95-14/2-T, para. 336; Prosecutor v. Kunarac, Kovac and Vukovic, Trial Chamber Judgment, 22 February 2001, ICTY Case No. IT-96-23, para. 402; Prosecutor v. Kunarac, Kovac and Vukovic, Appeals Chamber Judgment, 12 June 2002, ICTY Case No. IT-96-23, para. 56; Prosecutor v. Naletilic and Martinovic, Trial Chamber Judgment, 31 March 2003, ICTY Case No. IT-98-34-T, para. 177; Prosecutor v. Stakić, Case No. IT-97-24-T, Judgment, Trial Chamber II, 31 July 2003, para. 568; Prosecutor v Slobodan Miloševic, Decision on Motion for Judgment of Acquittal (Miloševic Rule 98bis Decision), ICTY Case No. IT-02-54-T, 16 June 2004, para. 16; Prosecutor v. Blagojevic and Jokic, Case No. IT-02-60-T, Judgment, Trial Chamber I, 17 January 2005, para. 536; Prosecutor v. Strugar, Case No. IT-01-42-T, Judgment, Trial Chamber II, 31 January 2005, para. 215; Prosecutor v. Limaj, Bala, and Musliu, Case No. IT-03-66-T, Judgment, 30 November 2005, para. 84; Prosecutor v. Orić, Judgment, Case No. IT-03-68-T, Trial Chamber II, 30 June 2006, para. 254; Prosecutor v. Haradinaj et al. , Judgment, Trial Chamber I, ICTY Case No. IT-04-84-T, 3 April 2008, paras. 37-49; Prosecutor v. Boškoski and Tarćulovski, Judgment, Trial Chamber II, Case No. IT-04-82-T, 10 July 2008, para. 175; Prosecutor v. Boškoski and Tarćulovski, Judgment, Appeals Chamber, Case No IT04-82-A, 19 May 2010, para. 21. 
either had to be 'a resort to armed force between States' (international armed conflict) or a situation of 'protracted armed violence between governmental authorities and organized armed groups or between such groups within a State' (non-international armed conflict). ${ }^{(17)}$

Once the existence of armed conflict is confirmed, international humanitarian law applies restricting the use of lethal force according to principles of humanity, distinction, proportionality and military necessity. For example, under the law of armed conflict commanders must take '[a]ll feasible precautions ... to avoid, and in any event to minimize, incidental loss of civilian life, injury to civilians and damage to civilian objects. ${ }^{\text {(18) }}$ It is prohibited to launch 'an attack which may be expected to cause incidental loss of civilian life, injury to civilians, damage to civilian objects, or a combination thereof, which would be excessive in relation to the concrete and direct military advantage anticipated' ${ }^{(19)}$

Rules concerning the use of lethal force under international human rights law are more stringent than under international humanitarian law. As stated above by Alston, the use of armed drones is 'almost never likely to be legal' if that status of the situation does not render international humanitarian law applicable. ${ }^{(20)}$ Although both bodies of law may apply simultaneously, in particular in situations of non-international armed conflict, the specific rules that will apply will require an assessment of the situation's status. The section that follow considers the challenge this specifically poses to the extraterritorial use of drones.

\section{The Applicability of International Humanitarian Law to the Use of Drones}

As mentioned above, international humanitarian law applies only where there is a situation of either international or non-international armed conflict. In either context, drones per se are not considered inherently indiscriminate or

(17) ibid

(18) J.M. Henckaerts and L. Doswald-Beck, Customary International Humanitarian Law: Volume 1, Rules (Cambridge University Press 2005), p. 51.

(19) J.M. Henckaerts and L. Doswald-Beck, Customary International Humanitarian Law: Volume 1, Rules (Cambridge University Press 2005), p. 46.

(20) UN Special Rapporteur on Extrajudicial, Summary or Arbitrary Executions, Study on Targeted Kil ings, UN Doc A/HRC/14/24/Add.6, 28 May 2010, para 85. 
perfidious. ${ }^{(21)}$ The 'use of drones is no different from a pilot dropping a bomb from a fighter jet, or a soldier firing a gun'. ${ }^{(22)}$ A key issue determining the legality of the use of drones for targeted killing concerns the geographical scope of the law of armed conflict.(23) Vogel notes that controversies surrounding drone warfare are not really about the weapon itself but, inter alia, 'defining the battlefield in a conflict with a transnational non-state actor'. (24) The geographic scope of the law of armed conflict has become a subject of considerable controversy, in particular since the initiation of US drone strikes in undeclared warzones after 11 September 2001. Given the geo-political significance of the United States, and its influence over the foreign policy of third States, this section will focus on the position adopted by the US for the extraterritorial use of lethal force by drones.

The approach adopted by the Government of the United States after 11 September 2001 - a position that has since maintained by different US government administrations - is that lethal force can be exercised without any geographic restriction provided the context is one of counterterrorism. This interpretation of the law was provided in 2012 by John Brennan, then a Legal Advisor to President Obama:

As the President has said many times, we are at war with alQa'ida ... Our ongoing armed conflict with al-Qa'ida stems from our right — recognized under international law-to self defense. ${ }^{(25)}$

(21) ICRC, 'The use of armed drones must comply with laws' (10 May 2013) <https://www.icrc.org/eng/ resources/documents/interview/2013/05-10-drone-weapons-ihl.htm > accessed 12 April 2019 ; Statement of David Glazier, Hearing on Rise of the drones II: Examining the legality of unmanned targeting, (28 April 2010), Committee on oversight and government reform, House of representatives, One hundred eleventh Congress, Second Session, 29.

(22) Philip Alston, 'Report of the Special Rapporteur on extrajudicial, summary or arbitrary executions' (2010) Human Rights Council Fourteenth session, Agenda item 3, para 79.

(23) See generally: ICRC, International humanitarian law and the challenges of contemporary armed conflicts, Doc. 32IC/15/11, Geneva: October 2015, Pp.12-16.

(24) Ryan Vogel, 'Droning On: Controversy Surrounding Drone Warfare Is Not Really About Drones' (2013) The Brown Journal of world affairs, 1-2.

(25) John O. Brennan, 'Strengthening our Security by Adhering to our Values and Laws', Harvard Law School, Cambridge, Massachusetts, 16 September 2011, available at $<$ https://obamawhitehouse.archives.gov/the-press-office/2011/09/16/remarks-john-o-brennan-strengthening-our-security-adhering-our-values-an>. 
The characterisation of the campaign as one of 'armed conflict' would have attracted less attention had it been limited to situations of active hostilities (for example, in Iraq and Afghanistan). However, the US position on the geographic scope of armed conflict is not one consistent with State practice in the field of international humanitarian law. ${ }^{(26)}$ The controversy generated by this more expansive approach to the use of lethal force was alluded to by Brennan:

An area in which there is some disagreement is the geographic scope of the conflict. The United States does not view our authority to use military force against al-Qa'ida as being restricted solely to 'hot' battlefields like Afghanistan. Because we are engaged in an armed conflict with al-Qa'ida, the United States takes the legal position that-in accordance with international law - we have the authority to take action against al-Qa'ida and its associated forces without doing a separate self-defense analysis each time. And as President Obama has stated on numerous occasions, we reserve the right to take unilateral action if or when other governments are unwilling or unable to take the necessary actions themselves. ${ }^{(27)}$

Brennan acknowledged that '[o]thers in the international communityincluding some of our closest allies and partners - take a different view of the geographic scope of the conflict, limiting it only to the "hot" battlefields.'(28) Indeed, the position of the UK government is substantially different to that of the United States. Commenting on the qualification of US campaign as one of 'armed conflict', Michael Fallon, the UK Minister of Defence stated:

It is for the Americans to defend or describe their own definition. We would consider on a case-by-case basis, where there is an armed conflict between government authorities and various organised armed groups, and we would look at various factors case-by-case ... such as the duration or

(26) However, see the position adopted by the US Supreme Court in Hamdan v. Rumsfeld, 548 U.S. 557 (2006).

(27) Ibid.

(28) Ibid. 
intensity of the fighting. ${ }^{(29)}$

The approach described by Fallon as UK Minister of Defence recognises the requirements that exist for the characterisation of non-international armed conflict under international humanitarian law. As noted by the Trial Chamber of the International Criminal Tribunal for Rwanda in the Musema case, 'whether a conflict meets the criteria of Common Article 3 is to be decided on a case by case basis.' ${ }^{(30)}$ Accordingly, an assessment of facts is necessary to determine the status of any given situation. In order for a non-international armed conflict to exist, as established in the Tadic case, the hostilities must reach a certain threshold of intensity and the parties must possess a sufficient degree of organisation. ${ }^{(31)}$ The approach taken by the United States is to conceive the existence of non-international armed conflict in global terms, making it unnecessary to assess the status of individual situations. As stated by Brennan, 'we have the authority to take action ... without doing a separate self-defense analysis each time.' ${ }^{\text {(32) }}$

US officials have claimed that the State is engaged in an ongoing armed conflict between 'al-Qa'ida, the Taliban and other associated forces'. ${ }^{(33)}$ In addition to the absence of any geographic restriction on the use of lethal force, this proposition is legally problematic because it imputes the actions of multiple, distinct non-state armed groups to al-Qa'ida. In order to attribute the actions of an armed group to Al-Qaeda, some assessment is required of the level of

(29) UK Parliament Joint Committee on Human Rights, Oral evidence: The UK Government's policy on the use of drones for targeted killing, HC 574, Wednesday, 16 December 2015, 3.

(30) Prosecutor v. Musema, Judgment and Sentance, Trial Chamber I, Case No. ICTR-96-13-A, 27 Jan ary 2000, para. 251.

(31) Prosecutor v Tadic, Case No. IT-94-1-T, Opinion and Judgement, May 7, 1997 at para 561-562

(32) John O. Brennan, 'Strengthening our Security by Adhering to our Values and Laws', Harvard Law School, Cambridge, Massachusetts, 16 September 2011, available at $<$ https://obamawhitehouse.archives.gov/the-press-office/2011/09/16/remarks-john-o-brennan-strengthening-our-security-adhering-our-values-an $>$ Another issue with the US position is that the law of armed conflict is conflated with the law governing the use of force in self-defence. For collection of relevant US legal and policy documents (including John Brennan's statement), see: Jammel Jaffer (ed), The Drone Memos: Targeted Killing, Secrecy, and the Law (New Press, 2016).

(33) President Barack Obama, 'Remarks by the President at the National Defence University' (23 May 2013) $<$ https://www.whitehouse.gov/the-press-office/2013/05/23/remarks-president-national-defenseuniversity > accessed 15 March 2019; Harold Koh, 'US Legal Adviser, The Obama Administration and International Law' (25 March 2010)< http://www.state.gov/s/l/releases/remarks/139119.htm > accessed 18 March 2019. 
control exercised by the leadership of al-Qa'ida over the armed group. ${ }^{(34)}$ The broad terms used to articulate the US position - referring to 'al-Qa'ida and its affiliates and adherents' - raises significant questions as to how assessments of status are undertaken for the use of lethal force. How is 'affiliation' defined? Is it necessary to be subject to chain of command or is mere association enough? No clarification has been provided on how 'affiliates' or 'adherents' qualify as legitimate targets. This conflation opens the door for a policy of targeting that does not comply with the requirements by international humanitarian law. As noted by Christine Gray, '[i]t is the substantive law that is crucial, and it is here that the USA's position is weakest'.(35)

Given the issues that exist with the US position, and the fact that drones continue to be procured by other countries for similar use, how should the use of such weapons be regulated? The section that follows posits some reflections on the application of international law, foreign policy, and the importance of third States ensuring accountability for the use of lethal force.

\section{Reflections on the Future of International Humanitarian Law and the Use of Force against Suspected Terrorists}

One of the most fundamental prerequisites for the effective regulation of drones is clarity concerning the applicable legal framework. As noted by Christof Heyns, Dapo Akande, Lawrence Hill-Cawthorne and Thompson Chengeta,

Though not inherently illegal weapons, drones do make the deployment of lethal force across borders much easier than before, and as such they pose significant risks to the protection of life. In this context the legal paradigm that is followed does make an important difference. If the assumption is that of a global noninternational armed conflict, to which IHL applies as the dominant legal regime, then it becomes much easier to justify lethal force, than if one takes the default legal framework of IHRL as the governing regime. ${ }^{(36)}$

(34) Kai Ambos and Josef Alkatout, 'Has 'Justice Been Done'? The Legality of Bin Laden's Killing Under International Law’ (2012) Israel Law Review 341, 350.

(35) Christine Gray, 'Targeted Killings: Recent US Attempts to Create a Legal Framework' (2013) 66 Current Legal Problems 75-p.106.

(36) Christof Heyns, Dapo Akande, Lawrence Hill-Cawthorne and Thompson Chengeta, 'The International Law Framework Regulating The Use of Armed Drones’ 65 (2016) International and Comparative Law Quarterly p. 826. 
Even in a situation where international humanitarian law applies and a drone strike is legal, the question must be asked as to 'whether it is wise to do so'.(37) Accordingly, international human rights law should be taken as default legal framework. ${ }^{(38)}$ 'Such an approach is the only way in which force remains the exception, thereby protecting the right to life in the long term' ${ }^{(39)}$

The importance of maintaining such protection is underlined by the changes that have occurred under the Trump administration with drone policy becoming 'less restrained, less transparent and less accountable'. ${ }^{(40)}$ The following three changes were stated in a report issued by the Stimson Center:

1) Expanding the targets of armed strikes by eliminating the requirement that the person pose an 'imminent threat';

2) Loosening the requirement of 'near certainty' that the target is present at the time of the strike to a 'reasonable certainty', and

3) Revising the process through which strike determinations are made by reducing senior policymaker involvement and oversight in such decisions and delegating more authority to operational commanders. ${ }^{(41)}$

Another worrying development is the expansion of areas of 'active hostilities', with the designation three more provinces in Yemen as areas falling within the category. ${ }^{(42)}$ A similar approach has affected operations in Somalia. ${ }^{(43)}$ Such measures increase the likelihood of death and injury to civilians in these

(37) Ib:d.

(38) Ib:d.

(39) Ib:d.

(40) Rachael Stohl, 'An action plan on US drone policy: Recommendation for the Trump administration' (Stimson, June 2018) $31<$ https://www.stimson.org/sites/default/files/file-attachments/Stimson\%20 Action\%20Plan\%20on\%20US\%20Drone\%20Policy.pdf > accessed at 8 July 2018

(41) Rachael Stohl, 'An action plan on US drone policy: Recommendation for the Trump administration' (Stimson, June 2018) $12<$ https://www.stimson.org/sites/default/files/file-attachments/Stimson\%20 Action\%20Plan\%20on\%20US\%20Drone\%20Policy.pdf > accessed at 8 July 2018.

(42) Charlie Savage and Eric Schmitt, 'Trump Administration Is Said to Be Working to Loosen Counterterrorism Rules', The New York Times, 12 March 2017, https://www.nytimes.com/2017/03/12/ us/politics/trump-loosen-counterterrorism-rules.html.

(43) Rachel Stohl, Under Trump, U.S. drone strike policy is looser and less transparent, (AXIOS, 14 June 2018) $16<$ https://www.axios.com/under-trump-us-drone-strike-policy-is-looser-and-less-transparent86c49069-b8eb-4a56-b950-b8b86004dc71.html > accessed at 10 April 2019. 
countries. ${ }^{(44)}$ Under the previous policy, an attack could only be ordered if there was 'near certainty' that a target was present and civilians would not be killed or harmed. Now those planning an attack need only show 'reasonable certainty'. This undermines the protection provided to the civilian population under international humanitarian law, with significant implications for principles of distinction and proportionality. Such policies set significant precedents and influence the behaviour of third States in their approach to the use of lethal force. On account of this, and in light of the violations that have been reported, the use of drones requires scrutiny to ensure their compliance with international law. ${ }^{(45)}$

According to Heyns, Akande, Hill-Cawthorne and Chengeta,

There is an urgent need for the international community to gain greater consensus on the interpretation of the constraints that international law in all its manifestations places on the use of drones. This is important not only because of the implications for those who currently find themselves on the receiving end of drones, but in order to keep a viable and strong system of international security intact. A central component of such a security system is the rule of law. Drones should follow the law, not the other way around. ${ }^{(46)}$

The issue is one of compliance with international law. In the context of armed conflict, the requirements of international humanitarian law must be adhered to. If war crimes are to be prevented, the protection the law provides to the civilian population should be not be compromised. In addition, international

(44) The Economist, 'How many civilians does America kill in air strikes?' (4 April 2019) < https:// www.economist.com/united-states/2019/04/06/how-many-civilians-does-america-kill-in-air-strikes> accessed at 10 April 2019.

(45) Nehal Bhuta, 'On Preventive Killing', (EJIL:Talk!, 17 Sep 2015) < https://www.ejiltalk.org/on-pr ventive-killing/ > accessed 28 March 2019.

(46) Written evidence from Christof Heyns, Dapo Akande, Lawrence Hill-Cawthorne and Thompson Chengeta (DRO0024), 'The Right to Life and the International Law Framework Regulating the Use of Armed Drones in Armed Conflict or Counter-Terrorism Operations', 10 December 2015, 46. See: Christof Heyns, Dapo Akande, Lawrence Hill-Cawthorne and Thompson Chengeta, 'The right to life and the international law framework regulating the use of armed drones' (2016) 65 International and Comparative Law Quarterly 791 at 826. See also: Summary of the Human Rights Council interactive panel discussion of experts on the use of remotely piloted aircraft or armed drones in compliance with international law: Report of the Office of the United Nations High Commissioner for Human Rights, UN Doc A/HRC/28/38, 15 December 2014, para 56. 
human rights law prohibits the deprivation of life. As noted in the conclusions of UN Human Rights Council Expert Panel:

The starting point of any legal analysis on armed drones should be existing international law, in particular the prohibition against the arbitrary deprivation of life. Modifying wellestablished rules of international law to accommodate the use of drones might have the unintended long-term consequence of weakening those rules. The existing legal framework was sufficient and did not need to be adapted to the use of drones, rather, it was the use of armed drones that must comply with international law. ${ }^{(47)}$

\section{Conclusion}

The challenge is one of ensuring greater compliance with international law. In addressing the obligation of States to 'respect and ensure respect', ${ }^{(48)}$ it is instructive to recall the shared interests that bind the international community. These interests are reflected in treaties of international law such as the Charter of the United Nations and the Geneva Conventions of 1949. They are also reflected rules of customary international law of an erga omnes nature: 'States may not encourage violations of international humanitarian law by parties to an armed conflict. They must exert their influence, to the degree possible, to stop violations of international humanitarian law. ${ }^{(49)}$

The obligation to prevent violations of international humanitarian law includes a duty to resist measures that undermine the protection provided by

(47) Summary of the Human Rights Council interactive panel discussion of experts on the use of remotely piloted aircraft or armed drones in compliance with international law: Report of the Office of the United Nations High Commissioner for Human Rights, UN Doc A/HRC/28/38, 15 December 2014, para 56.

(48) Article 1 common to the four Geneva Conventions states: 'The High Contracting Parties undertake to respect and to ensure respect for the present Convention in all circumstances.' Geneva Convention for the Amelioration of the Conditions of the Wounded and Sick in Armed Forces in the Field, August 12 1949, 6 U.S.T. 3114, 75 U.N.T.S. 31; Geneva Convention for the Amelioration of the Conditions of the Wounded and Sick and Shipwrecked Members of Armed Forces at Sea, August 12 1949, 6 U.S.T. 3217, 75 U.N.T.S. 85; Geneva Convention Relative to the Treatment of Prisoners of War, August 12 1949, 6 U.S.T. 3316, 75 U.N.T.S. 135; Geneva Convention Relative to the Protection of Civilian Persons in Time of War, August 12 1949, 6 U.S.T. 3516, 75 U.N.T.S. 287.

(49) J.M. Henckaerts and L. Doswald-Beck, Customary International Humanitarian Law: Volume 1, Rules (Cambridge University Press 2005), p. 509. 
the law. The characterisation of the campaign against al-Qa 'ida or ISIS as an armed conflict of global dimensions weakens the framework upon which the applicability of the law is based. It also obscures the distinction that has existed from time immemorial between war and peace, with deleterious consequences for accountability.

The continuing lack of accountability for the extraterritorial use of lethal force creates fertile conditions for future conflict. As such, it poses a pressing challenge for the maintenance of international peace and security. If international peace and security are not protected, the threat to the international legal order is an existential one. Accordingly, there is an urgent need for issues of compliance with international law to addressed. 


\section{References}

- Cullen, Anthony, 'The Characterisation of Remote Warfare under International Humanitarian Law' in Jens David Ohlin (ed), Research Handbook on Remote Warfare (Gloucester: Edward Elgar Press, 2017),

- Gray, Christine, 'Targeted Killings: Recent US Attempts to Create a Legal Framework' (2013) 66 Current Legal Problems 75-106.

- Heyns, Christof, Dapo Akande, Lawrence Hill-Cawthorne and Thompson Chengeta, 'The International Law Framework Regulating the Use of Armed Drones' 65 (2016) International and Comparative Law Quarterly 791-827.

- ICRC, International humanitarian law and the challenges of contemporary armed conflicts, Doc. 32IC/15/11, Geneva, October 2015.

- Mir, Sana, The Use of Armed Drones by the United States Against A1,Qaeda and its 'Associates': A Study of Law and Policy Arising from a 'State of Exception', PhD Thesis, November 2018.

- OHCHR, Summary of the Human Rights Council interactive panel discussion of experts on the use of remotely piloted aircraft or armed drones in compliance with international law: Report of the Office of the United Nations High Commissioner for Human Rights, UN Doc A/ HRC/28/38, 15 December 2014.

- UK Parliament Joint Committee on Human Rights, The Government's policy on the use of drones for targeted killing: Second Report of Session 2015-16, HC 574, HL Paper 141, 10 May 2016.

- UN Special Rapporteur on Extrajudicial, Summary or Arbitrary Executions, Study on Targeted Killings, UN Doc A/HRC/14/24/Add.6, 28 May 2010. 


\section{Table of Contents}

\begin{tabular}{|l|l|}
\hline Subject & Page \\
\hline Introduction & \\
\hline $\begin{array}{l}\text { The Proliferation of Drone Technology and the Context for the } \\
\text { Use of Drones in Armed Conflict }\end{array}$ & \\
\hline The Characterisation of Armed Conflict & \\
\hline $\begin{array}{l}\text { The Applicability of International Humanitarian Law to the Use } \\
\text { of Drones }\end{array}$ & \\
\hline $\begin{array}{l}\text { Reflections on the Future of International Humanitarian Law and } \\
\text { the Use of Force against Suspected Terrorists }\end{array}$ & \\
\hline Conclusion & \\
\hline References & \\
\hline
\end{tabular}

